\title{
「ながら」の周辺的な意味用法に関するー考察 \\ A Study of the Peripheral Usage of nagara
}

\section{村松 由起子 \\ 豊橋技術科学大学}

\section{要旨}

「ながら」は初級後半ぐらいで学ぶ比較的やさしい形式であるが、周辺的な意味 用法には類義表現もあり、それらは日本語教育ではほとんど扱われてこなかった。 本稿では、「ながら」を基本的な用法、状況的な説明を表す用法、手段的な説明 を表す用法に分け、後者 2 つを周辺的な意味用法として位置づけた。この周辺的 な意味用法について、中上級レベルの学習者が習得できているかを文法性判断 テストにて確認したところ、正答率が低く、必ずしも習得できているとは言え ないことが示唆された。この結果を踏まえ、周辺的な「ながら」について、類義 表現との使い分けの視点から教える必要性があるかを、類義表現の一つ「うち に」を取り上げて考察し、使い分けが必要であることを明らかにした。

キーワード :

ながら、習得、状況的、手段的、うちに 


\section{「ながら」の周辺的な意味用法に関する一考察}

\section{村松 由起子 \\ 豊橋技術科学大学}

\section{1.はじめに}

「ながら」は初級後半ぐらいで学ぶ比較的やさしい形式であるが、周辺的な 意味用法ついては、従来、日本語教育ではほとんど扱われてこなかった。また、 「ながら」の周辺的な意味用法には「うちに」などの類義表現もあり、使い分け の問題もある。本稿では、文法性判断テストにて中上級レベルの学習者が 「ながら」の周辺的な意味用法を習得できているかを探り、類義表現との使い 分けを学習者に教える必要があるか否かを考察する。

\section{2.「ながら」の扱いとその問題点}

「機能語用例データベース「はごろも」Ver.2」で「Vながら」を確認してみる と、意味は「付带状況」「同時（並行）」、難易度は初級後半となっており、用例 としては「おんがくをききながら、べんきょうします。」などが挙げられている。

この主節の動作に同時並行的に付随する動作を表す意味用法が「ながら」の 基本的な意味用法であり、一見すると学習者にとっては習得しやすい形式の ように思われる。

実際に、日本語学習者の「ながら」の誤用を観察した研究もあり、韓国語 母語話者については鄭・坂口(2001)が、中国語母語話者については建石(2007) がある。鄭・坂口は韓国語母語話者には「ながら」の誤用が見られることを 指摘しているが、建石は「KYコーパス」にて誤用を観察した結果として、 中国語母語話者には同時を表す接続助詞「ながら」「つつ」「がてら」に関する 誤用がほとんど見られないことを指摘している。建石(2007:112) は誤用が 少ない要因として、一つは中国語にも「ながら」とよく似た形式 “一边〜一边” があること、もう一つは同時を表す接続助詞の習得そのものがそれほど難しく ないこと、の二つの可能性があり、このうちどちらの可能性が高いかは慎重に 検討する必要があるとしている。また、市川（2010）の『日本語誤用辞典』に も「ながら」の項目はないことから、誤用観察という点からは、一般的には 「ながら」はやさしい形式だといえるかもしれない。 
しかし、本当に「ながら」は学習者にとってやさしい形式だと言えるの だろうか。次の用例を見てみたい。

（1）テレビを見ながらご飯を食べた。（基本的な同時）

（2）本を読みながら寝てしまった。(状況的な同時)

（3）タオルで京きながら髪の毛を乾かした。(手段的な同時)

（1）は初級の段階で学ぶ「ながら」の基本的な意味用法である。(1)に 対して(2)(3)には状況説明的な意味や手段的な意味が加わっており、(2)(3) は周辺的な意味用法に位置づけられるであろう。(2)の「読みながら」は「寝て しまった」ときの状況説明的な意味を持ち、( 3 )の「ふきながら」は「乾かす」 ための手段的な意味を持っている。日本語教育では、従来、この(1)(2)(3)の

「ながら」の意味用法を区別しないで扱ってきた。

(2)( 3 )の周辺的な意味用法には類義表現もあり、(2)の場合だと ( 2 )'のよう に「読んでいるうちに」、(3)の場合だと ( 3 )'のように「ふいて」を用いること も可能である。

( 2 )’ 本を読んでいるうちに寝てしまった。

( 3 )’ タオルで尒いて髪の毛を乾かした。

果たして、中上級レベルの学習者は(2)(3)の周辺的な「ながら」の意味用法 を習得できているのだろうか。習得に問題がある場合、これらの周辺的な意味 用法とその類義表現の使い分けを教える必要があるのではないだろうか。この 検証を行うため、本稿では以下 $1 、 2$ 手順で考察を行っていくことにする。

1. 中上級レベルの学習者に対して文法性判断テストを行い、周辺的な 「ながら」の意味用法の成立を正しく判定できるかを調查する。

2.これらの周辺的な「ながら」と類義性を持つ他の形式について、日本 語教育として使い分けを教える必要があるかを考察する。

考察に入る前に、1、2 の手順に先立って、付帯状況を表す「ながら」に ついて、教科書での扱い及び先行研究を見ておく。 


\section{3.「ながら」の先行研究}

まず、日本語教科書での扱いから見ていく。ここでは『みんなの日本語初級』 を取り上げる。

『みんなの日本語初級』では「ながら」は「II」の第 28 課で登場し、文法説明 は以下のようになっている。なお、用例に付されているふりがなは省略する。

This sentence pattern indicates that someone performing an action indicated by $\mathrm{V} 1$ is simultaneously performing a separate action indicated by V2, where V2 indicates the main action:

(1) 音楽を聞きながら 食事します。

I listen to music while eating.

It is also used to describe someone doing two things continuously over a period of time:

(2) 働きながら 日本語を 勉強しています。

I'm working while studying Japanese. (p.24)

このように、初級での「ながら」はV2を主動作とした 2 つの動作の同時進行 （付帯状況）を表す形式として導入されており、学習者の母語に「ながら」 に対応する形式がある場合も多いことから、この基本的な意味用法に関しては、 比較的導入しやすい形式だと思われる。

次に、先行研究ではどのように扱われているのかを、日本語教育文法、 日本語記述文法、対照研究の先行研究から一つずつ挙げておく。

日本語教育文法の視点からの先行研究として、ここでは庵他(2000)を取り 上げる。庵他(2000:193)では「「Pながら Q」という文型は付帯状況の一つで、 ある主体が動作 $\mathrm{Q}$ を行うときに同時に別の $\mathrm{P}$ を行うことを表します。このとき $\mathrm{P}$ は時間的な幅のある動作であることが必要です。」との説明があり、類義表現 についてはテ形に触れて、「Pながら Q」を意味を変えずに「Pて Q」に置き 換えることはできないとし、次(4)のa「使いながら」を「て」にした b「使って」 は、手段の意味になると述べている。

（4）a.資料を使いながら勉強した。

b.資料を使って勉強した。 
庵他(2000)では「ながら」と「て」の類義性については触れられているが、「な がら」は付帯状況、「て」は手段であり、異なる意味として扱っている。しかし、 (4)a の「使いながら」にも手段的な意味が含まれており、また、次の( 5 )の ように「ながら」と「て」を置き換えても意味に差が感じられない場合もある。

（５）a.わからない語彙が多かったので、辞書を使いながら勉強した。 b.わからない語彙が多かったので、辞書を使って勉強した。

なお、庵他(2000)では、「うちに」などその他の類義表現については触れられ ていない。

次に日本語記述文法の視点からの先行研究として、ここでは付帯状況表現「な がら」「たまま」「て」の3 形式の差異を扱った三宅(1995)を取り上げる。

三宅(1995)は森山(1988)の時定項分析に基づき、この3 形式が付帯状況として 成立する条件を考察しているので、まず、森山の時定項について簡単に触れて おく。森山(1988)は動詞について、「過程」を持つ場合は「〜はじめる」「〜つづ ける」の両方が使え、「維持」を持つ場合は「〜つづける」のみが使え、「結果 持続」の場合は両方とも使えないとしており、三宅(1995)はこの「過程」「維持」 「結果持続」を用いて 3 形式を考察している。

三宅(1995:450)は「ながら」成立条件について次のようにまとめている。

「過程」を持つ動詞の場合、付帯状況として成立する。ただしその場合、 主節に対する相対的な「過程」であってもよい。「過程」を持たない動詞の 場合は、基本的に不成立であるが、繰り返しの意味の場合、または 「維持」を持つ動詞の場合は、成立することがある。これらは「過程的な 持続性を持つ場合に成立する」としてまとめることができる。尚、動詞 が「維持」を持つ場合は、タママ、テに置き換えが可能な場合がある。

つまり、「過程」を持つ動詞の場合（過程的な持続性を持つ場合を含む）に 「ながら」が使え、「過程」に加えて「維持」も持つ場合はタママやテに置き換え ができる場合がある、ということになる。ただし、三宅(1995)は「置き換えが 可能な場合もある」と述べるにとどまっており、どのような動詞の場合に置き 換えができるかまでは具体的に述べていない。また、「うちに」など状況を説明 する形式との類義性については触れられていない。 
最後に、対照研究の視点からの先行研究として村松(2017)を取り上げる。 村松(2017:24)は中国語と日本語の付帯状況を表す形式を対照させた研究であり、 日本語の「ながら」には中国語の“一边〜一边”にはない状況的な説明を表す 意味用法 ${ }^{1}$ があることを指摘し、次の用例では「ながら」が中国語の「时（とき）」 に対応しているとしている。

（6）杏子は坂を降りながら、いつか自分が一人になっていることに気付 いた。

(往坡下走时, 杏子发现剩下孤身一人, 于是停住脚步叫乙醇, 但无 回音 ${ }^{2}$ 。)（あした来る人）

この（6）では「とき」との類義性が認められ、状況的な「ながら」には 本稿の最初で示した「うちに」以外にも類義性のある形式があることがわかる。

村松(2017)は、この状況的な「ながら」は中国語の “一边〜一边”の形式に 対応しないため、両形式の意味用法にはずれがあると述べている。

三宅(1995)の「ながら」と「たまま」「て」との置き換え条件や村松(2017)で指摘 されている「ながら」の状況的な意味用法については、日本語教育にはまだ 生かされてはいないと言えよう。

\section{4.「ながら」の意味用法}

ここで、先行研究を踏まえて「ながら」の意味用法を次の表 1 にまとめて おく。

表 1 付帯状況「ながら」の意味用法

\begin{tabular}{|l|l|}
\hline \multicolumn{1}{|c|}{ 型 } & \multicolumn{1}{c|}{ 用例 } \\
\hline$\langle 1>$ 基本的な同時並行の意味用法 & テレビを見ながらご飯を食べた。 \\
\hline$\langle 2>$ 状況的な意味用法 & 本を読みながら寝てしまった。 \\
\hline$\langle 3 〉$ 手段的な意味用法 & タオルでふきながら髪の毛を乾かした。 \\
\hline
\end{tabular}

1 村松(2017)はこの状況的な意味用法について「V1の動作が進行している状況下でV2の 瞬間動作が生じることを表す」と説明している。(p.25)

2 用例出典『中日対訳コーパス』にて確認すると、中国語に対応する日本語としては 「杏子は足を停めた。アルさんの名を呼んだが返事はなかった。」が続く。 
$<1>$ は従来から日本語教育で扱われている基本的な付帯状況で、「テレビを 見ながらご飯を食べた」のような「ながら」である。

$<2>$ は村松(2017)で示されている状況的な説明を表す「ながら」で「本を 読みながら寝てしまった」のような「ながら」である。

$<3>$ は庵他(2000)、三宅(1995)などの先行研究でも付帯状況のテ形との 置き換えで取り上げられてきた手段的な説明を表す「ながら」である。

$<1><2>3>0 う ち 、<2><3>$ は周辺的な意味用法に位置づけられると 考える。この周辺的な「ながら」については、従来、日本語教育ではほとんど 取り上げられていないため、学習者が果たしてこれらの「ながら」を習得でき ているのか、以下、文法性判断テストによって探ってみる。

\section{5. 文法性判断テスト}

では、今回行った文法性判断テストとその結果について述べる。調査目的は 「ながら」の周辺的な意味用法（状況的、手段的）について、中上級レベルの 学習者が習得できているかを文法性判断テストによって探ることである。

なお、今回の調査はパイロット的に実施したものであり、習得に問題がある と確認できた場合は、確認できた問題点に焦点を当ててさらに詳細な調査を 実施する計画である。調査対象者と日本語のレベルは表 2 の通りである。レベルに ついては日本語能力試験を受験していない者もいたため、学習歴、受講クラス のレベルをもとに目安として示しておく。

表 2 調查対象者

\begin{tabular}{|c|c|c|}
\hline 学習者 & レベル & 人数 \\
\hline 中国人学習者 & N1 レベル相当 & 45 名 \\
\hline その他学習者 & N2 レベル相当以上 & 26 名 \\
\hline 全体 & N2 レベル相当以上 & 71 名 \\
\hline
\end{tabular}


調査は全部で 71 名に対して行った。内訳は中国人学習者 45 名、マレーシア人 学習者 20 名、ベトナム人学習者 2 名、ラオス人学習者 2 名、インドネシア人 学習者 1 名、カンボジア人学習者 1 名である。

中国人学習者が最も多く、45 名いたので、全体の集計とは別に中国人学習者 のみでも集計を行った。調査対象者の日本語のレベルはN $2 \sim \mathrm{N} 1$ 相当で あった。中国人学習者は日本の日本語学校で学んでいる学習者であり、その他 学習者は日本の大学で日本人と一緒に学んでいる大学生である。

調査文は、ダミーの他、「〜たり〜たり」などの同時並行に関連する形式を含め て 35 文あり、学習者には $\bigcirc \times$ 形式で文法性判断をしてもらった。今回は調査文 のうち、状況的な「ながら」文と手段的な「ながら」文について分析していく。

35 の調査文については、日本語ネイティブ 10 名に判定してもらい、8 名以上 が「言える」とした文を分析の対象とした。対象とした文と各文の意味用法を 表 3 に示す。

表 3 分析した調査文

\begin{tabular}{|l|l|}
\hline \multicolumn{1}{|c|}{ 調査文 } & 意味用法 \\
\hline 1. 本を読みながら寝てしまった。 & 状況的 \\
\hline 2. タオルでふきながら髪の毛を乾かした。 & 手段的 \\
\hline 3. 氷をたたきながら少しずつ割った。 & 手段的 \\
\hline 4. スープが熱かったので、かき混ぜながら冷ました。 & 手段的 \\
\hline
\end{tabular}

「状況的」に該当する調査文は「1.本を読みながら寝てしまった」、「手段的」 に該当する調査文は「2.タオルでふきながら髪の毛を乾かした」「3.水をたたき ながら少しずつ割った」「4.スープが熱かったので、かき混ぜがら 冷ました」である。 
「状況的」については調査の段階では 3 文判定してもらつたのだが、そのう ち 2 文 $^{3}$ ついては日本語ネイティブでも判定が分かれたため、今回の分析対象 は1文のみとなった。調査文は実例をもとに調査用に作例したものであるが、 「状況的」な「ながら」については、必要な文脈の有無が判定に影響を及ぼす可能 性もある。今後、日本語ネイティブの判定が分かれた要因を分析した上で、より 妥当性を高めた調査が必要であるが、今回は日本語ネイティブにゆれがなかった 1 文のみを扱うことにする。

\section{6. 文法性判断テストの結果と分析}

今回の調査では、周辺的な意味用法との比較のために、基本的な意味用法も 調査文に含めてあったので、まず、基本的な意味用法の正答率を示しておく。

基本的な意味用法として、「お菓子を食べながら友だちとゲームで遊んで いる」を判定してもらったところ、中国人学習者の正答率は $84.4 \%$ 、その他 学習者が $87.5 \%$ 、全体では $83.1 \%$ と、8 割以上が正答しており、高い正答率が 得られた。

では、周辺的な意味用法の結果はどうであったか。「状況的」な意味用法から 見ていきたい。

表 4 状況的な「ながら」の正答率

\begin{tabular}{|c|c|c|}
\hline \multirow{2}{*}{ 調查文 } & 正答率 & 対象者 \\
\hline \multirow{2}{*}{1. 本を読みながら寝てしまった。 } & $28.9 \%$ & 中国人学習者 \\
\cline { 2 - 3 } & $57.7 \%$ & その他学習者 \\
\cline { 2 - 3 } & $39.4 \%$ & 全体 \\
\hline
\end{tabular}

1 の文について、中国人学習者では「言える」と判定した人は $28.9 \%$ と低く、 約 7 割の学習者が「言えない」と回答した。その他学習者は $57.7 \%$ なあった ため、この文については学習者の母語によって正答率に差が生じる可能性が

3 日本語ネイティブの判定が分かれた調査文は次の 2 文である。「野菜を切りながら指を 切ってしまった」「熱があるのにマラソン大会に参加したので、走りながら倒れてし まった」。いずれもネイティブ 10 名の判定は $04 、 \times 6$ であった。一方、分析の対象とした 「本を読みながら寝てしまった」の判定は $09 、 \times 1$ であった。 
あるが、 $57.7 \%$ も高い数字とは言えないため、全体としては正しく判定でき ない可能性のあることが示唆された。妥当な調查文を増やして詳細な調查を する必要はあるが、少なくとも 1 の文については、中上級レベルの学習者でも 習得できていない可能性があることがわかった。

次に、「手段的」な意味用法について結果を見てみる。

表 5 手段的な「ながら」の正答率

\begin{tabular}{|c|c|c|}
\hline 調查文 & 正答率 & 対象者 \\
\hline \multirow{4}{*}{ 2.タオルでふきながら髪の毛を乾かした。 } & $35.6 \%$ & 中国人学習者 \\
\cline { 2 - 3 } & $73.1 \%$ & その他学習者 \\
\cline { 2 - 3 } & $39.4 \%$ & 全体 \\
\hline \multirow{2}{*}{ 3.水をたたきながら少しずつ割った。 } & $42.2 \%$ & 中国人学習者 \\
\cline { 2 - 3 } & $61.5 \%$ & その他学習者 \\
\cline { 2 - 3 } & $49.3 \%$ & 全体 \\
\hline \multirow{2}{*}{ 4. スープが熱かったので、かき混ぜながら } & $48.9 \%$ & 中国人学習者 \\
\cline { 2 - 3 } 冷ました。 & $69.2 \%$ & その他学習者 \\
\cline { 2 - 3 } & $56.3 \%$ & 全体 \\
\hline
\end{tabular}

中国人学習者で「言える」と判定した人は、 2 が $35.6 \% 、 3$ が $42.2 \% 、 4$ が $48.9 \%$ とす心゙て $50 \%$ 未満であり、「言えない」と考えている学習者が多いことが わかった。

一方、その他学習者は 2 が $73.1 \% 、 3$ が $61.5 \%$ 、 4 が $69.2 \%$ と 3 文とも $60 \%$ 以上の正答率であったことから、学習者の母語など何らかの要因によって正答 率に差が生じている可能性があるが、この「手段的」な「ながら」についても、 必ずしも習得できているとは言えない可能性のあることが確認できた。

以上の結果から、中上級レベルの日本語学習者であっても、「ながら」の周辺 的な意味用法である「状況的」「手段的」な意味用法については必ずしも習得 できているとは言えない可能性があり、特に「状況的」な意味用法については 中国人学習者、その他学習者とも正答率が低いことがわかった。 
学習者の習得状況を明らかにするには、分析可能な用例を増やし、さらに 詳細な調査をする必要があるが、今回の調査で、少なくとも「ながら」の周辺的 な意味用法、特に「状況的」な意味用法については習得できているとは言えない 可能性が示唆された。

習得に問題がある場合、それらの類義表現との使い分けができていない 可能性もあり、また、使い分けが必要な場合は、教える際も類義表現との違い を意識して教えていく必要がある。そこで、以下では、文法性判断テストにて 判定に問題のあった「状況的」な「ながら」との類義表現の一つである「うち に」を取り上げ、状況を表す意味用法として「ながら」と「らちに」を使い分 ける必要があるのかを考察してみる。

なお、両形式にはどのような使い分けがあるのかの詳細な考察は今後の 課題とし、本稿では使い分ける必要があるのか、つまり、いずれかしか使え ない場合があり、誤用が生じる可能性があるのかについて考えてみる。

\section{7. 状況を表す意味用法としての「ながら」「うちに」の使い分けの必要性}

まず、「ながら」と「うちに」の使い分けの必要性について、市川(2010)の誤 用例をもとに見ていきたい。市川(2010)には「ご飯を食べているらちに、話す のはあまり好きではない。<中国・香港＞」という誤用が紹介されており、 この正用は「ご飯を食べているときに話すのは、あまり好きではない。」となって いる。市川(2010)では「とき」を用いて訂正されているが、この誤用では「らち に」を「ながら」にして「ご飯を食べながら話すのは、あまり好きではない」 とすることもできるため、「ながら」が使えていない誤用とも捉えることが できる。つまり、「うちに」と「ながら」の使い分けが必要なケースとも考え られる。

次に両形式の使い分けの必要性を、「ながら」と「うちに」の類義性及び置き 換えの可否の点から見てみる。市川(2018:530、531)では「うちに」は「一定の 時間・期間内に状態・行為が終了する」形式の一つとして、「〜とき/ときに」 「〜あいだに」「〜うちに」「名詞＋中に」「まえに/までに」「ないうちに」の中 で取り上げられている。市川は「うちに」の意味用法として次の 2 つをあげて いる。1つ目は、「1つの状態が続いている時間・期間内に、また、その状態が 変化する前に、物事を済ませてしまうという意味合い。「うちに」の前に「〜て いる」等の状態性の表現が来る。ここでは状態が変化することに対する懸念の 気持ちが入る」としている。(7)( 8$)$ は市川(2018)の用例である。なお、下線は 本稿による。 
（7） 子供が寝ているうちに、買い物に行ってこよう。

（8）スペインに留学しているうちに、フラメンコを習っておきたい。

この意味用法の場合、市川は「物事を済ませてしまう」としていることから、 主節は意図的な行為が想定される。一方、「ながら」の状況的な意味用法の 場合は、（2）「寝てしまった」、( 6 )「気付いた」のように主節は非意図的な 行為が想定されることから、この 1 つ目の意味用法については、「ながら」との 類義性は低いと考えられる。

さらに、もう一点、(7)の用例から「うちに」と「ながら」の違いを述べてお くと、( 7 )では主節と従属節の主語が異なっているが、「ながら」の場合は 同一主体でなければならない。異主体が成り立つか否かも両形式の違いである。

2 つ目は、「一定の時間・期間が経過していくときに、他の現象も同時に引き起 こされることを表す」という意味用法であり、(9)(10) はこの意味用法の用例 である。

（9）日本語を勉強しているうちに、だんだん日本語が好きになっていった。

（10）彼の説明を聞いているうちに、ますますわからなくなってしまった。

「ながら」との使い分けが問題になるのは、この 2 つ目の「一定の時間・期 間が経過していくときに、他の現象も同時に引き起こされることを表す」意味 用法であろう。この用法には、「V1 うちに」が、同時に引き起こされる主節の V2 が起こる状況を述べる場合が含まれている。「うちに」と「ながら」は、主 節のV2 が起こる状況を表しているという点において共通しているといえる。

次の(11)(11)'の用例は「うちに」も「ながら」も使えるケースになる。

（11）本を読んでいるうちに寝てしまった。((2)'の再掲)

(11)’本を読みながら寝てしまった。（(2)の再掲）

さらに置き換えが可能な用例を挙げておく。

（12）車を走らせているうちに、ふっとあの店に行ってみる気になりま したの。(黒白の囮)

(12) 車を走らせながら、ふっとあの店に行ってみる気になりましたの。 (作例) 
（13）聴いているうちに、「ああ、いいなあ」などと思ったわけです。 (Yahoo!ブログ)

（13）＼cjkstart聴きながら、「ああ、いいなあ」などと思ったわけです。（作例）

ただし、この意味用法であっても上記の市川の用例(9)(10)では「うちに」を 「ながら」に置き換えにくいことから、2つ目の意味用法でも、「ながら」に 置き換えや寸い場合と置き換えにくい場合のあることがわかる。

（９）？?日本語を勉強しながらだんだん日本語が好きになっていった。

(10)？?彼の説明を聞きながらますますわからなくなってしまった。

「ながら」と「うちに」がどのような条件で置き換えが可能になり、どの ような場合に置き換えられないのか。使い分けについては、今後、さらに詳しく 考察する必要があるが、現段階としては、(9)’(10)’が言えないのは、「好きに なる」「わからなくなる」は、「好きになりつづける」「わからなくなりつづける」 とは言えないことから、三宅(1995)の「ながら」の成立条件である「過程」を 持つという条件を満たしていないことによるという説明も可能だと考える。

また、次の(14) (14)’は主節が( 2 )と同じ「寝てしまった」であるが、(14)の 「うちに」であれば異主体の解釈ができるので、「泣いていた子が寝て しまった」という状況が想定できて自然な文となるが、(14)’の「ながら」は 同一主体でなければならないため、「料理しながら寝る」という不自然な状況に なり、成立しない。このように異主体であることによって使い分けが必要な 場合もある。なお(14)は少納言の用例をもとにした作例である。

（14）泣く子をおんぶして料理しているうちに寝てしまった。（作例）

(14)＇＊泣く子をおんぶして料理しながら寝てしまった。（作例）

\section{8. まとめと今後の課題}

本稿では、日本語学習者にとって比較的やさしいと考えられている「ながら」 について、基本的な意味用法と周辺的な意味用法を区別し、周辺的な意味用法 について中上級レベルの学習者に習得上の問題がないかを探索してみた。その 結果、「ながら」の「状況的」、「手段的」な意味用法について、中上級レベルの学習 者でも文法性の判断に問題があることが示唆され、これらの周辺的な「ながら」 
の意味用法について、日本語教育としての扱いを検討する必要性を示すことが できた。

今まで日本語教育では周辺的な意味用法の「ながら」とその類義表現との 使い分けについては、付帯状況のテ形は多少触れられているものの、本格的な 使い分けまでは導入されているとは言い難く、また、テ形以外の類義形式に ついては触れられてこなかった。今回、本稿の考察により、中上級レベルの 学習者でも「ながら」の周辺的な意味用法の習得に問題があることが示された ため、今後は、より詳細に学習者の習得状況の調查をし、「うちに」「とき」など の類義表現との使い分けの条件を明らかにしていきたい。 


\section{「ながら」の周辺的な意味用法に関する一考察}

\section{参考文献}

庵功雄・高梨信乃・中西久実子・山田敏弘(2000)『初級を教える人のための日本語文法 ハンドブック』スリーエーネットワーク

庵功雄・高梨信乃・中西久実子・山田敏弘(2001)『中上級を教える人のための日本語文法 ハンドブック』スリーエーネットワーク

市川保子編(2010)『日本語誤用辞典』スリーエーネットワーク

市川保子(2018)『日本語類義表現の使い方のポイントー表現意図から考えるー』スリーエー ネットワーク

建石始(2007)「中国語母語話者の同時を表す接続助詞の習得について:「ながら」「つつ」「が

てら」を中心に」『神戸大学留学生センター紀要』13, pp.103-115

鄭恵先・坂口昌子(2001)「誤用分析にもとづく「ながら」と「吕」の比較一始点の用法

と述語の持続性を中心に一」『世界の日本語教育』11, pp.153-166, 国際交流基金 三宅知宏(1995)「〜ナガラと〜タママと〜テ一付帯状況の表現一」『日本語類義表現の文法

(下)』pp.441-450, くろしお出版

村松由起子(2017)「付帯状況表現に関する日中対照研究一「〜ながら」「〜て」と“一边 V1

一边 V2”“V1 着 V2”一」『中国語話者のための日本語教育研究』8, pp.16-31, 日中言語文化 出版社

森山卓郎(1988)『日本語動詞述語文の研究』明治書院

\section{参考資料}

機能語用例データベース「はごろも」Ver.2

\section{用例出典}

現代日本語書き言葉均衡コーパス $(\mathrm{BCCWJ})$ (少納言)

北京日本学研究センター(2003)『中日対訳コーパス』第 1 版 
<文法性判断テスト調査文>

今回の文法性判断テストは、同時進行、同時並行の形式について習得上の問題点を 探るため、「〜たり〜たり」「〜ながら〜ながら」などの形式も取り上げて、パイロット的 に行ったものである。そのため、調査文には本稿では取り上げなかったものも多い。

\section{【調查文】}

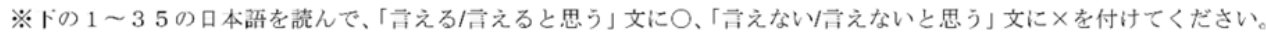

\begin{tabular}{|c|c|}
\hline 1 & 頭が㛚かったので薬を飲んで早く誛た。 \\
\hline 2 & マラソン大会に参加して、走ったり歩いたりゴールを目指した。 \\
\hline 3 & 水をたたきながら少しずつ割った。 \\
\hline 4 & (自分で組み立てるタイプの) ベッドが笛いたので、ベッドを組み立てて説明書を見た。 \\
\hline 5 & 彼女は闵書館で資料を見ながらネットで調べながらレポートを書いた。 \\
\hline 6 & お肙は食堂で食べたりコンビニでお弁当を買って食べている。 \\
\hline 7 & 子供の世話をしながら料理のレシピを見ながら晚ごはんを作つている。※レシビ:作り方 \\
\hline 8 & 本を読みながら寝てしまった。 \\
\hline 9 & 日本に来てから日本語の勉強を「あいらえ扰なからはじめた。 \\
\hline 10 & タオルでふきながら髪の毛を乾かした。 \\
\hline 11 & なんとかホデルに着きながら地図を見た。 \\
\hline 12 & 京都に行ったとき写真をたくさん撮ってSNSにのせた。 \\
\hline 13 & 野菜を切りながら指を切ってしまった。 \\
\hline 14 & たばこを吸ったりビールを飲んだり大声でさわいでいる。 \\
\hline 15 & いつも音楽を聞きながら歌いながら审を運転している。 \\
\hline 16 & 装を読んでいるうちに樶くなってきた。 \\
\hline 17 & 漢字は誖んだり苦いたりしないとなかなか覚えられない。 \\
\hline 18 & $\begin{array}{l}\text { 彼女はカフェでコーヒーを飲みながらケーキを食へながら友だちと旅行の } \\
\text { スケジュールを相談している。 }\end{array}$ \\
\hline 19 & 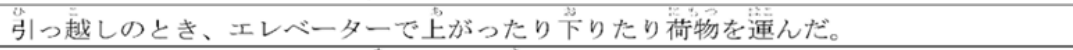 \\
\hline 20 & スープが熱かったので、かき混ぜながら椧ました。 \\
\hline 21 & 子供たちがベッドの上で飛んだりはねたり遊んでいる。 \\
\hline 22 & 日嚁日は部屋を墇除したり買い物に行ったり友だちとカラオケに行ったりしている。 \\
\hline 23 & 唂があるのにマランン大会に参加したので、走りながら倒れてしまった。 \\
\hline 24 & 授業中は教科苦を見ながらノートを取りながら先生の話を閶いている。 \\
\hline 25 & アルパイトをしてパソコンを買ったのにすぐに壊れてしまった。 \\
\hline 26 & たばこを吸いながもビールを拎みながら大声でさわいでいる。 \\
\hline 27 & 風が吹きながら雨も降っている。 \\
\hline 28 & いつもバスが来るまで本を誖んだり友だちと話をしたり待っている。 \\
\hline 29 & もうすぐ授業が始まるので急いで教室に入った。 \\
\hline 30 & コーヒーを飲みながら䓔えながら狧題をした。 \\
\hline 31 & 体調が悪いなら今早は早く寝たほうがいい。 \\
\hline 32 & 携带電話で話したりメールを見たり歩くのは危ないのでやめたほうがいい。 \\
\hline 33 & お菓子を食べながら友だちとゲームで遊んでいる。 \\
\hline 34 & 彼は会議のとき、資料を見たり記録を取ったりしながら報告を閶いている。 \\
\hline 35 & 田中さんが説明しながら鈴木さんが閐いている。 \\
\hline
\end{tabular}

※ご協力ありがとうございました。 